Владимир Р. Поломац

Универзитет у Крагујевцу

Филолошко-уметнички факултет

Одсек за филологију, Катедра за српски језик

v.polomac@filum.kg.ac.rs
УДК 811.163.1"14"

https://doi.org/10.18485/slavistika.2021.25.1.10

Оригинални научни рад примљено 19.04.2021.

прихваћено за штампу 17.06.2021.

\title{
О ПРАВОПИСУ И ЈЕЗИКУ ПИСАМА ДЕСПОТА ВУКА ГРГУРЕВИЋА
}

У раду се истражују најважније правописне и језичке одлике четирију писама деспота Вука Гргуревића (у народној традицији познатог под именом Змај-Огњени Вук), упућених турском султану Бајазиту II током 1482. и 1483. године, као и једног писма упућеног 1483. године Бајазитовом војном заповеднику Али-бегу Михалоглуу. Наведена писма значајна су као сведочанство употребе српског језика у дипломатској преписци која је из Угарске од краја 15. века вођена са турским султанима и обласним заповедницима. Претежним одсуством одлика ресавског правописа истраживана писма одступају од главнине повеља и писама деспота Ђурђа Бранковића и његових наследника. С друге стране, употребом српског језика у чијој се основици препознају особине косовско-ресавског дијалекта 15. века, писма деспота Вука Гргуревића успостављају континуитет са повељама и писмима Српске деспотовине и писмима из канцеларија турских султана Мехмеда II и Бајазита II упућеним Дубровнику.

Кључне речи: српски језик, дипломатски језик, деспот Вук Гргуревић, Змај-Огњени Вук, историјска дијалектологија, 15. век.

The paper investigates the most important orthographic and linguistic features of four letters by Despot Vuk Grgurević addressed to the Turkish Sultan Bayezid II during 1482 and 1483, as well as a letter sent in 1483 to Bayezid's military commander Ali Bey Mihalbegović. The aforementioned letters serve as a significant testimony to the use of the Serbian language in the diplomatic correspondence conducted from Hungary with the Turkish sultans and regional commanders in the late $15^{\text {th }}$ century. Due to the predominant absence of the features of Resavian orthography, the letters in question deviate from the majority of the charters and letters of Despot Đurađ Branković and his successors. On the other hand, by using the Serbian language based on the recognizable features of the Kosovo-Resavian dialect of the $15^{\text {th }}$ century, letters by Despot Vuk Grgurević establish a continuity with charters and letters of the Serbian Despotate, along with the letters from the offices of the Turkish sultans Mehmed II and Bayezid II.

Keywords: Serbian, language of diplomacy, Despot Vuk Grgurević, historical dialectology, $15^{\text {th }}$ century.

1. Од деспота Вука Гргуревића, сина слепог Гргура Бранковића и унука деспота Ђурђа Бранковића, у народној традицији познатијег под именом ЗмајОгњени Вук, сачувано је до данас пет писама из девете деценије 15. века: 1) писмо султану Бајазиту о миру и пријатељству (5. јун 1482, Купиник), 2) веровно писмо султану Бајазиту II за његовог слугу Мурата (1482-1483), 3) писмо Али-бегу Михалоглуу којим препоручује свога изасланика Јована (1483), 4) веровно писмо султану Бајазиту II за његовог изасланика Мурата (27. јун 1483, Ириг), и 5) писмо султану Бајазиту II о склапању мира (1483). ${ }^{1}$ Будући да деспо-

${ }^{1}$ Ни у једном од наведених писама у тексту није наведена година настанка. За прва три писма Никола Радојчић (1953-1954: 351) сматра да су настала 1481. године, а као аргумент наводи чињеницу да се у првоме писму помиње султан Бајазит II коме деспот Вук Гргуревић 
та Вука Гргуревића приказују „не само као истакнутог крајишког заповедника, већ и као вештог дипломату који је активно учествовао у преговорима који су 1482-1483. вођени у циљу закључења примирја између султана Бајазита II и краља Матије Корвина" (Митровић 2006: 66), наведена писма представљају значајно сведочанство о употреби српског као дипломатског језика у преписци која је из Угарске од краја 15. века вођена са турским султанима и војним и обласним заповедницима, ${ }^{2}$ те као таква завређују детаљније филолошко и лингвистичко истраживање.

Прва три писма позната су нам на основу издања Николе Радојчића (19531954: 353-355) које је приређено према фотографијама оригинала (из истанбулског Сараја) добијених од немачког турколога Франца Бабингера (уп. Радојчић 1953-1954: 350). ${ }^{3}$ Овим фотографијама - које се данас чувају у Архиву САНУ под сигнатурама 10070-1, 10070-3 и 10070-4 - користили смо се и ми у овоме раду. Четврто и пето писмо познати су нам захваљујући немачком истраживачу Адолфу Дајсману, који их је заједно са другим неисламским рукописима пронашао у истанбулском Сарају. Он је фотографије писама уступио бугарском историчару Ивану Гошеву који их је први објавио 1932. године (Гошевъ 1932: 262-269) да би наредне године Дајсман донео преводе писама на немачки језик (Deissmann 1933: 102-105). Фотографије су затим преко Ивана Гошева и Станоја Станојевића дошле до Љубомира Стојановића који је њихове текстове објавио у другој књизи старих српских повеља и писама (Стојановић 1934: 487-489). Фотографија четвртог писма објављена је касније у Ђорђић 19913: 358 , док се фотографији последњег писма губи сваки траг. Идући за поменутом Дајсмановом студијом (1933), као и каснијим радовима о словенским рукописима у истанбулском Сарају (Харисијадес 1964-1965), покушали смо да дођемо до оригинала писама деспота Вука Гргуревића. Међутим, приликом посете Топкапи палати у Истанбулу (у новембру 2019. године) обавештени смо да

изјављује верност као новом турском господару. Катарина Митровић (2006: 73) прихвата мишљење Симе Ћирковића (1981: 387), који настанак првог писма везује за 1482. годину, а онда, сходно томе, претпоставља да би наредно писмо могло бити издато 1482 . или 1483. године, а треће 1483. године (в. Митровић 2006: 74-75). За четврто писмо преузели смо датирање Станоја Станојевића (уп. Deissmann 1932: 102), док за пето писмо Катарина Митровић (2006: 79) наводи да је настало током лета или почетком јесени 1483. године.

2 Поред наведених писама деспота Вука Гргуревића позната су нам још два српска писма из девете деценије XV века упућена из Угарске: писмо краља Матије Корвина султану Бајазиту II од 25. јуна 1487. године (уп. издање у Радојчић 1953-1954: 363-364) и писмо Стефана Баторија, дворског судије и ердељског војводе, Али-бегу Михалоглуу (1482-1489) (уп. издање у Радојчић 1953-1954: 362-363).

3 Уколико изузмемо велики број примера за оу на месту 하, у Радојчићевом издању треба исправити следеће грешке: у првом писму уместо своюи 6 , са те(м) 6, вг 8х2, зємхю 10/11, први 12 , w(т) зимлюе(м) 24/25, тою 26, никедла 27, сь сви(м) 28, долази према нашем читању своши 6,

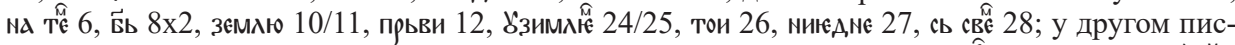

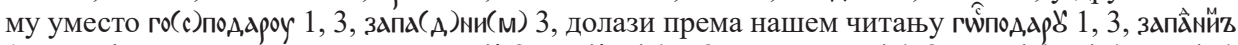
1; у трећем писму уместо храварств 10, принема(м) 14, нашо(м) 14, 15, ниюедна $16 \times 2$, Боса(н)ски(X) 29, долази према нашем читању

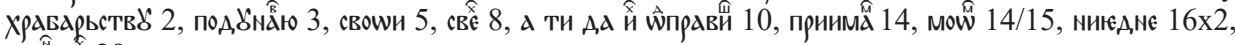
БосÄ́Kе́ 29. 
се тамо данас налази само турска копија писма Али-бегу Михалоглуу, али не и српска писма која су предмет овога рада. С обзиром на наведене околности, наше истраживање засновано је на грађи из прва четири писма, док је грађа из петог писма узимана селективно само као контролни корпус на основу већ поменутог Стојановићевог издања. ${ }^{4}$

Писма деспота Вука Гргуревића остала су до данас у целини непроучена са филолошке и лингвистичке стране. О писмима располажемо само са неколико узгредних филолошких коментара Николе Радојчића (1953-1954: 352) наведених уз издање текста, као и са неколико палеографских напомена Петра Ђорђића (19913: 125-127). Тако Радојчић (1953-1954: 352) за прво и треће писмо каже да су писани „или руком невештом или рукописом нечитким”, „углавном, чистим говорним језиком”, док за друго писмо наводи да је писано „китњастим рукописом од стране вешта писара". 5 Уз начела за приређивање текста писама Радојчић (1953-1954: 352) напомиње како „,акцената у писмима има мало”, да су изостављани из издања „пошто су ударани без смисла и неконсеквентно”, а у вези са интерпункцијом примећује како је „тачка уношена у текст мало изнад линије". Палеографске напомене Петра Ђорђића (19913: 125-127), засноване само на фотографији четвртог писма, односе се на морфолошке облике слова 3 , м, \&, ч, ж, и и н у контексту развитка српског брзописа у 15 . веку након престанка рада државних канцеларија.

Основни циљ нашег рада представља покушај да се сагледају најважније правописне одлике писама у контексту ресавске правописне школе, као и најважније језичке одлике у контексту дијалекатске диференцијације српских говора на територији некадашње Српске деспотовине и јужне Угарске крајем 15. века. Правописне и језичке одлике писама посматране су у ширем оквиру који нам пружају повеље и писма деспота Ђурђа Бранковића и његових наследника (према Поломац 2012а, 2012б, 2013, 2016, Ивић 1973), употреба српског језика у дипломатској преписци угарског двора у 15. и 16. веку (према Поломац 2018, 2020), као и употреба српског језика у преписци турских султана 15. и 16. века са Дубровником (према Лутовац Казновац 2019).

2. Истраживање је показало да су најважније одлике ресавског правописа у писмима деспота Вука Гргуревића веома слабо одражене. За сва писма карактеристично је одсуство графеме ы, као и доследно обележавање гласовне групе

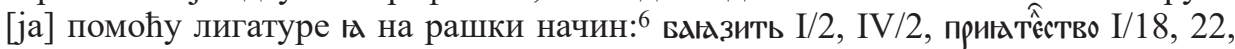

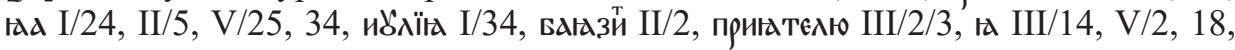

${ }^{4}$ На основу поређења са фотографијом објављеном у Ђорђић 19913: 358 може се закључити како је Стојановићево издање четвртог писма верно оригиналу, те да у њему треба поправити само једну грешку: уместо први 12 треба прьви 12. Следствено томе, може се претпоставити и да Стојановићево издање петог писма такође верно одражава оригинал, те да се може узети барем за контролни корпус.

${ }^{5}$ К. Митровић (2006: 78) износи претпоставку да је нека од Вукових писама могао својом руком саставити поп Јован, његов поклисар, личност несумњиво учена и упућена у тајне дипломатије.

${ }^{6}$ Примери се наводе тако што се римским бројем означава редни број писма према хронологији настанка (в. списак писама у претходној тачки), а арапским бројем ред у оригиналу. Примери из петог писма навођени су према реду у издању љ. Стојановића. 


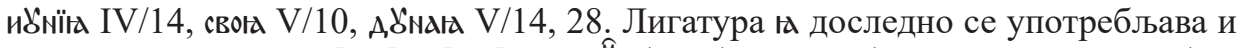
за означавање група [ља] и [ња]: зємлґй I/2, II/2, волґа II/15, 17, 20, кралґа III/25, покланіамо II/7, конґа IV/9.

Изолованим или малобројним примерима потврђене су графеме z и ї, као и употреба надредних акценатских знакова. Тако би о графеми z могло бити речи само у примеру запа̂мйz II/1, у коме надредно м и z чине лигатуру. Графема ї употребљава се само у двама примерима, у функцији обележавања /и/ испред /j/ у страним називима месеци: иઠ̌лї̈а I/34, иઠ̆нї̈ IV/14. У првоме писму бележи се више примера за и у овој позицији: приғате́єтво I/22, ниюдмє I/27, док у кратком тексту четвртог писма нема других примера за /и/ испред /j/. У трећем и петом писму /и/ испред /j/ бележи се помоћу и и ь: приғтелю III/2/3, ниюднє III/16x2, прнгатество V/4, 32, принателю V/7, али зАравью III/3, веселью III/3, знаньюе V/12, хадыє V/23, 26. ${ }^{7}$ Посебно стоје примери са надредним словом и титлом: хотеє

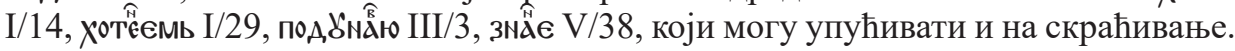

Запажањима Николе Радојчића (1953-1954: 352) о малобројним примерима и неконсеквентној употреби акценатских знакова потребно је додати и да се у писмима нешто већим бројем потврда бележи само двострука варија (кендема). Овај знак најчешће долази уместо очекиваног спирита изнад графеме $w,{ }^{8}$ ређе изнад є и ю: свош"и I/6, III/5, виш" порذччиш" I/13, говориш" I/30, писаш" III/6, иш̈вана III/12, иш̈щє III/20, иӥвай III/20; стоёки I/19, твою̈ III/8. Вероватно се на овај начин могу објаснити и примери: царй II/1, порбфчнлй II/3, колйкс II/4/5. У складу са традицијом пословноправне писмености Српске деспотовине (уп. Поломац 2016: 146-156) двострука варија се употребљава у функцији обележавања квантитета у облицима сложене придевске деклинације: вєлики I/2, 3, прьвй I/12, 20, въьику II/2, чєститй IV/3, облицима именица и заменица: рьчй II/3 (ген. мн.), мй I/5, 14, 19, III/9, IV/11 (ном. мн.), тй III/10 (ном. јд.), ${ }^{9}$ чӧ I/5, III/17, IV/8, као и у основинском делу и наставцима глагола: прймисм I/4, змӓ IV/3 (3. л. јд. през.). Поред двоструке варије, на квантитет упућује и удвајање вокала у облику ном. јд. личне заменице 1. л.: ґд I/24, II/5, V/25, 34, као и у 3. л. јд. презента: знда II/3, Алd IV/11, V/8, 10. Од интерпункцијских знакова забележена је само тачка, употребљена „мало изнад линије”, како ју је већ описао Н. Радојчић (19531954: 352).

Највише правописних варијација у писмима бележи се у вези са обележавањем гласовне групе [je]. Доследном употребом є одликује се само друго писмо: єрњ II/3, є II/4. У првом писму бележи се знатно више примера за є него за лигату-

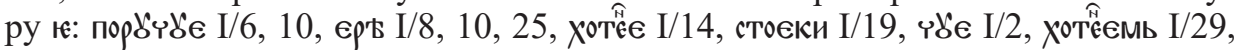

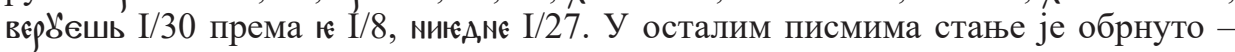

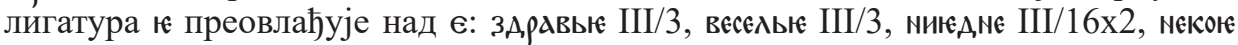

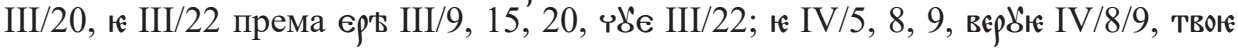

${ }^{7}$ Могуће је да се у наведеним примерима са ь огледа утицај Портине српске канцеларије (уп. Лутовац Казновац 2019: 84-85).

${ }^{8}$ Писање двоструке варије изнад графеме w одлика је неколико писама султана Мехмеда II Дубровнику из осме деценије 15. века (уп. Лутовац Казновац 2019: 107).

${ }_{9}^{9}$ Аналогијом према облицима номинатива заменица $т и$ и ми долази двострука варија и у дат. јд.: мй III/6, тй II/2, 3×2, 4×2. 
IV/4 према ер' IV/4; свою V/6, 25, 26, твон V/7, 9, 13, 16, 19, 25, 33, знаные V/12,

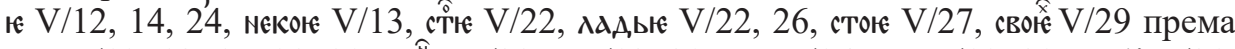

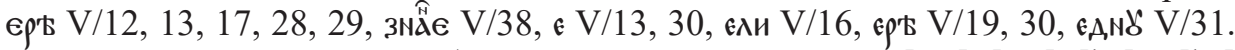
C друге стране, приликом обележавања гласовних група [ље], [ње], [ће] и [ђе] употребљава се само лигатура к: крдлєємь I/12, кралюєвє I/24, 26, III/15, V/11, 21,

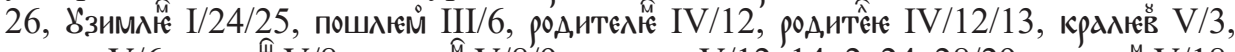

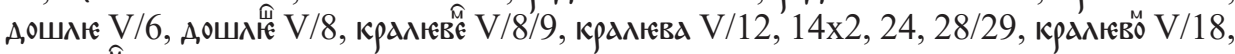

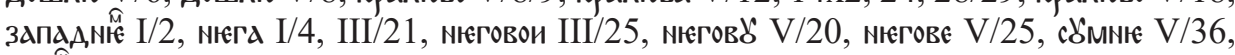

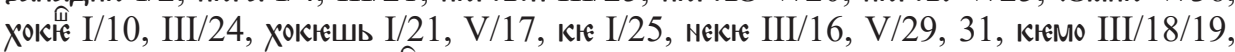
Хокюе $\mathrm{V} / 7,37,31, \mathrm{~V} / 20$, неккё $\mathrm{V} / 19$, д, оге I/4, погке III/7.

На основу наведених правописних одлика може се закључити како писма деспота Вука Гргуревића одступају од стања које је забележено у главнини повеља и писама деспота Ђурђа Бранковића и његових наследника. Правопис писама деспота Вука Гргуревића најсличнији је правопису писма деспота Стефана Бранковића Дубровнику (1. октобар 1476). У овоме писму изостају графеме z и ї, изостаје а у функцији [ja] (доследно лигатура ґа), изостају акценти и спирити и употреба интерпункције, а графеме ы и є (у функцији [је]) потврђене су само једним примером (уп. Поломац 2013: 131). У осталим писмима деспота Лазара и Стефана Бранковића, као и у писмима султаније Маре, одлике ресавског правописа знатно су заступљеније (уп. Поломац 2013: 128-131, Ивић 1973: 340). Одсуство одлика ресавског правописа у писмима деспота Вука Гргуревића, као и у случају писма деспота Стефана Бранковића Дубровнику из 1476. године, може се објаснити њиховим световним карактером, али и друштвеноисторијским контекстом у коме су настали. Време опште несигурности након смрти деспота Ђурђа Бранковића и пада Српске деспотовине морало је оставити трага и на делатност писара у канцеларијама његових наследника (уп. Поломац 2013: 132). С друге стране, правопис писама деспота Вука Гргуревића сличан је правопису великог броја писама турских султана Мехмеда II и Бајазита II упућених Дубровнику (уп. Лутовац Казновац 2019: 293), што указује на могуће узајамне утицаје писмености из времена Српске деспотовине (и времена након њеног пада) и писмености Портине српске канцеларије.

3. С обзиром на стање у повељама и писмима деспота Ђурђа Бранковића и његових наследника (уп. Поломац 2012а: 134-141, 20126: 343-350), и у писмима деспота Вука Гргуревића очекујемо петочлани вокалски систем: /a/, /e/, /и/, /o/, /y/, у коме су одржане промена /ě/ > /e/, /ə/ y /a/, вокалног /л/ у /y/ и /л/ на крају слога у $/ \mathrm{o} /$.

Графема ' п пише се на етимолошком месту најчешће у вези са $\rho$, у карактеристичној лигатури: ${ }^{10}$ пр'ввисоко $\mathrm{I} / 1$, прьскаิ

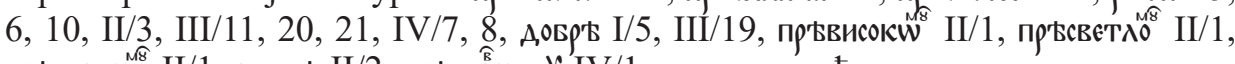

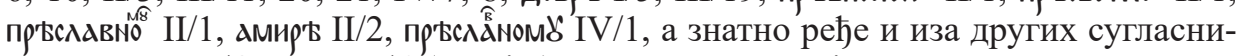
ка: в'ьровдло II/4, тев' III/6 (дат. јд.). У истим позицијама долази и примери са овом графемом на месту етимолошког /*е/: єењ I/8, 10, 25, II/3, III/9, 15, 20, IV/4,

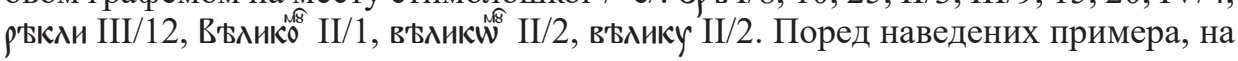

${ }^{10}$ Наведена лигатура карактеристична је и за писма турских султана Мехмеда II и Бајазита II Дубровнику (уп. Лутовац Казновац 2019: 42-43). 
екавизам писама недвосмислено упућују примери писања є на месту етимолошког /*е̌/:

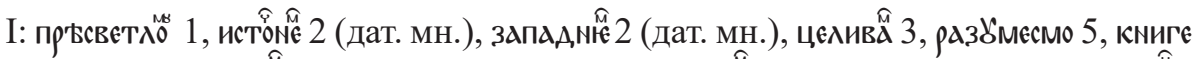

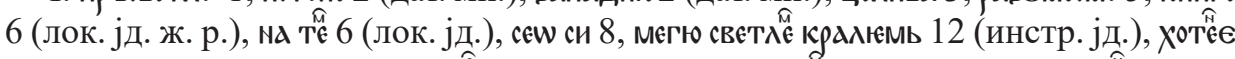

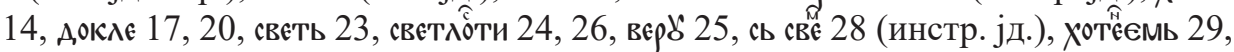
верУॄешь 30.

II: пр'єсвєт А⿱

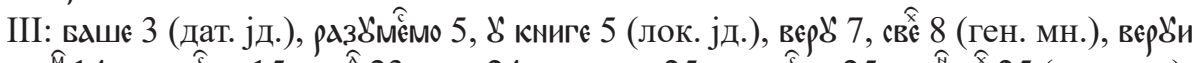
14, веро 14, светлотти 15, Хоте 23, вера 24, светлога 25, светлоти 25, восӓске 25 (ген. мн.).

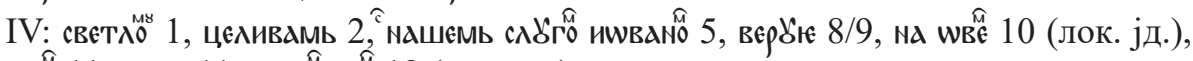

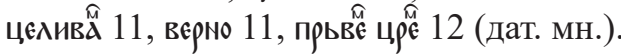

$\mathrm{V}:$ Wнем кралюевิ

Из наведене грађе посебно се издвајају примери екавизма у одређеним морфолошким категоријама значајни као сведочанство процеса формирања косовско-ресавског дијалекта од краја 14. и током 15. века: а) дат. и лок. јд. именица ж. р.: вашє III/3 (дат. јд. некадашње палаталне промене), ชै книгє I/6, III/5, по слঠге 4, по вод̊ V/15 (лок. јд. некадашње непалаталне промене);11 б) облици придевских заменица са наставцима некадашње непалаталне промене: сь свй $\mathrm{I} / 28$

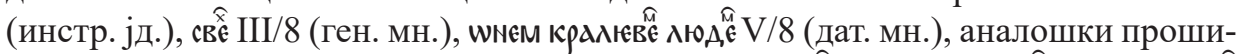
рени и на друге облике унутар парадигме: мегю свет

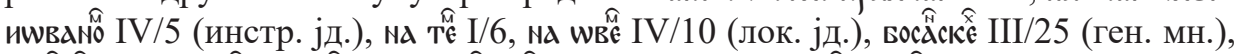

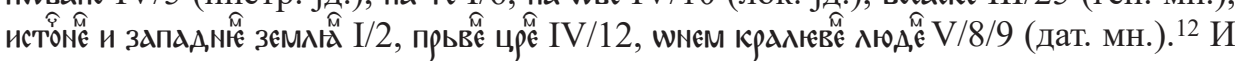
док се у лок. јд. именица женског рода, као и у инстр. јд. придевских заменица и придева наставци -е и -ем срећу доследно, у лок. јд. придевских заменица и

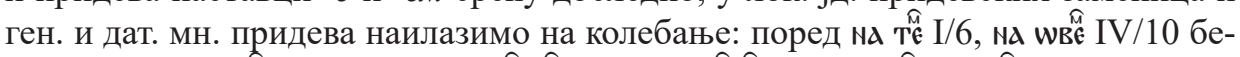

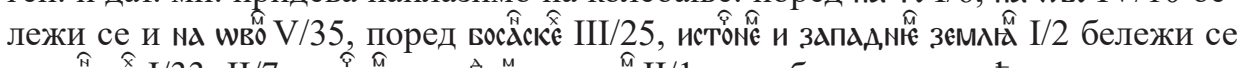

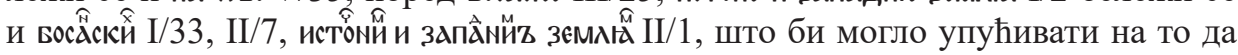

${ }^{11}$ Наведени примери забележени су и у другим пословноправним споменицима од краја 14. и током 15. века: у Струшком препису Душановог законика (уп. Грицкат-Радуловић 1975 : 134), повељама и писмима кнеза Лазара и Вука Бранковића (уп. Стијовић 2008: 462, Поломац 2017: 66-67), у повељама и писмима деспота Стефана Лазаревића и деспота Ђурђа Бранковића (уп. Стијовић 2008: 462, Поломац 2012а: 136, 2016: 167-168), у повељама и писмима деспота Лазара и Стефана Бранковића (уп. Поломац 2012б: 325-327), у писмима султаније Маре (уп. Ивић 1973: 338), као и у Рударском законику деспота Стефана Лазаревића (уп. Јовић 1968/1969: 406-407) и писмима турских султана Дубровнику (уп. Лутовац Казновац 2019: 188). За примере овога типа у говорима косовско-ресавског дијалекта уп. само Ивић 1994: 222.

12 Примери су забележени и у повељама и писмима кнеза Лазара и Вука Бранковића (уп. Стијовић 2008: 464-466, Поломац 2017: 67), повељама и писмима деспота Стефана Лазаревића и деспота Ђурђа Бранковића (уп. Поломац 2012а: 136-137, 2012б: 346, 2016: 167-168), писмима султаније Маре (Ивић 1973: 338-339), у Рударском законику деспота Стефана Лазаревића (уп. Јовић 1968/1969: 417-418, 425-427), као и у писмима турских султана Дубровнику (уп. Лутовац Казновац 2019: 360). За стање у говорима косовско-ресавског дијалекта уп. само Ивић 1994: 223, 2009: 65. 
процес уопштавања косовско-ресавских наставака још увек није био завршен. ${ }^{13}$ С друге стране, о снази тенденције уопштавања косовско-ресавских наставака у нашим писмима сведочи чињеница да се примери са -ех и -ем у ген. и дат. мн. придева пробијају и у формулаичним уводним и завршним деловима писама, у којима се начелно очекује конзервативније стање.

Иако се морфолошки икавизам бележи у писму деспота Стефана Бранковића

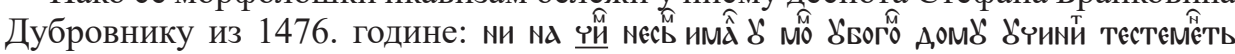
(уп. Поломац 20126: 346, 2016: 168), иако су најмање два писма деспота Вука Гргуревића настала на територији данашњег Срема (прво у Купинику, четврто у Иригу), у њима нису потврђени примери икавизама који би могли упућивати на постанак шумадијско-војвођанског или смедеревско-вршачког дијалекта крајем 15. века.

Изузев четвртог писма у коме нису забележени примери вокала /a/ пореклом од некадашњег /ə/, у свим осталим писмима ова промена је потврђена: ${ }^{14}$ тадь

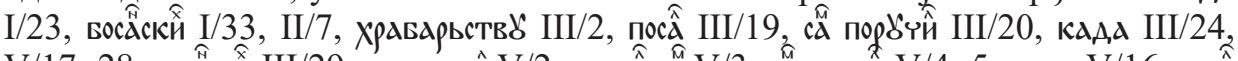

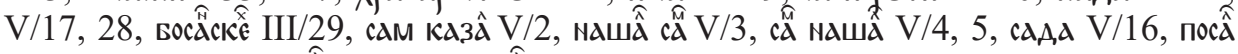

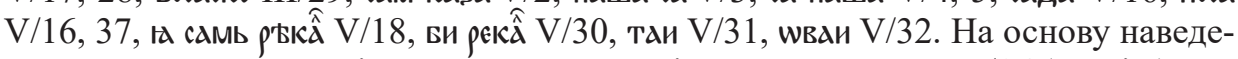
них потврда разложно је претпоставити да је у примеру льжє III/16 (ген. јд.), вокал /a/ обележен на традиционалан начин графемом ь.

Судбина некадашњег вокалног /л/ у писмима деспота Вука Гргуревића може се пратити само на основу његовога имена у потпису: во̆кь I/33, III/28, IV/17, В̌́ III/6. ${ }^{15}$ Већим бројем потврда посведочена је промена /л/ на крају слога у

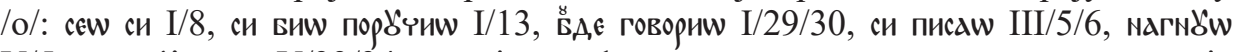
$\mathrm{V} / 5$, си порбчєваш V/33/34, што је такође очекивано у контексту података које нам пружају повеље и писма деспота Лазара и Стефана Бранковића, у којима је ова промена „системска одлика језика посведочена неспорним примерима” (Поломац 2012б: 350). ${ }^{16}$ Примери у којима је /л/ на крају слога непромењено долазе са надредним словом и титлом на крају речи, те као такви имају првенстве-

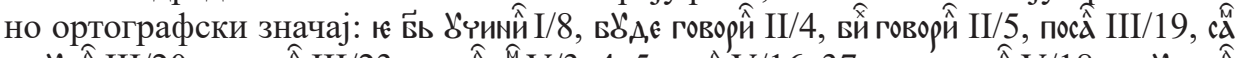

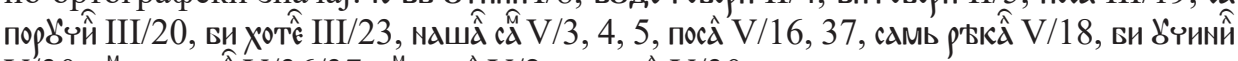

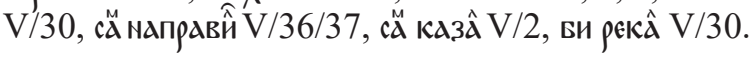

Остале важније фонетске и фонолошке одлике језика писама деспота Вука Гргуревића, забележене и писмима султаније Маре (уп. Ивић 1973: 339-340),

${ }^{13}$ На исти закључак упућује и грађа из писама султаније Маре (уп. Ивић 1973: 338-339).

${ }^{14}$ Вокал /a/ пореклом од некадашњег /ə/ забележен је и у повељама и писмима деспота Стефана и Лазара Бранковића (уп. Поломац 20126: 349, 2016: 171). С друге стране, чување полугласника претпоставља П. Ивић (1973: 343) за писма султаније Маре Бранковић.

${ }^{15}$ Потврде ове промене очекиване су с обзиром на стање других споменика пословноправне писмености 15. века из источних штокавских крајева: примери се бележе у Рударском законику деспота Стефана Лазаревића (Јовић 1968/1969: 383), двема повељама деспота Ђурђа Бранковића из треће деценије 15. века (Поломац 2012а: 139-140) и повељама и писмима деспота Лазара и Стефана Бранковића (Поломац 2012б: 349). У писмима султаније Маре нема примера за вокално /л/ (Ивић 1973: 339).

${ }^{16}$ Промена /л/ на крају слога у /о/ забележена је и у писмима султаније Маре (уп. Ивић 1973: 339). 
нису од значаја за дијалекатску диференцијацију српских говора у другој половини 15. века, али представљају важно сведочанство о превласти српског над српскословенским језиком у нашим писмима. Иницијално $y$ - пореклом од вbдоследно је одражено у духу српског језика (๖ I/6, 9, 16, 34, III/2, 5, IV/14, V/9,

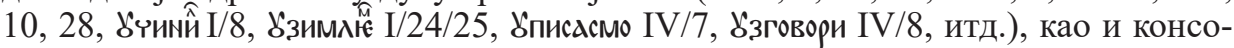
нанти /h/ и /h/ у резултату новог јотовања -jm- и -jд-: доки V/9, А.югє I/4, III/26, А.огошє IV/4, А.ггю V/22, нагомо I/16, погю III/7. Поред примера метатезе у заменич-

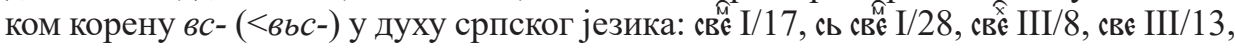
свдки V/30, забележен је и један српскословенски пример всдкє III/1 у уводној формули писма. Предлог и префикс од редовно се пишу са надредним А: $\mathbf{w} \mathrm{I} / 4$, $23,24,26$, II $/ 4$, III $/ 7,13,15,16,18 x 2,21$, IV/4, V/10, 36, พิправй III/10, พิхชัчило $\mathrm{V} / 13$, к $10,25, \mathrm{II} / 3, \mathrm{III} / 9,15,20, \mathrm{IV} / 4, \mathrm{~V} / 12,13,17,28,29$, єрь V/19, 30, док очекивано изостаје у глаголу можє I/16. Поред многобројних примера групе (-)um- пореклом од (-)чьт-: чо I/5, 7, 9, 13х2, 26, 29, III/5, 11, 13, 17, 22, IV/5, 8, 9, V/19, 33, 37 , чे II $/ 4$, ничо V/19, бележи се и традиционално писање у примерима потенога I/28, поттене III/1, Пӧтени III/5, Пӧтенога III/10.

4. Поред горенаведених примера дат. и лок. јд. ж. р. непалаталне и палаталне промене са наставком -e, у именичкој деклинацији су од највеће важности потврде наставка - $a$ у ген. мн. м. р.: све вдшдлдра III/8, своюе поклисара V/29 (поред грал, ${ }^{\widehat{B}} \mathrm{I} / 33, \mathrm{II} / 7, \mathrm{III} / 29$ у формули потписа), ${ }^{17}$ као и примери који би могли

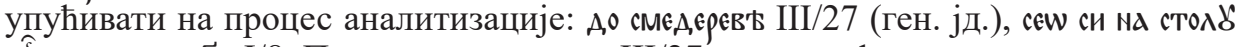
цртва свога шца I/8. Пример д, смєдєрєв' III/27 може упућивати на мешање генитива и локатива у једнини, ${ }^{18}$ док други пример може илустровати мешање акузатива и локатива. ${ }^{19}$ У писмима нису забележени примери који би упућивали на преструктурирање множинских падежа након губљења двојине: само зємлґ⿱ $\mathrm{I} / 2$, II/2 (дат. мн. ж. р.) и цри I/1, II/1, цри III/1 (инстр. мн. м. р.), али у уводним формулама адресације. Посебну пажњу завређују још и двојаки облици инстр. јд. м. р. некадашњих палаталних основа (крахюмь I/12, али и цхей V/1) и ном. мн. м. р. по консонантској промени (родитієеㅌ IV/12, али и поклисари V/21, 23, 27), као и при-

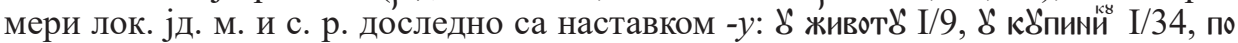

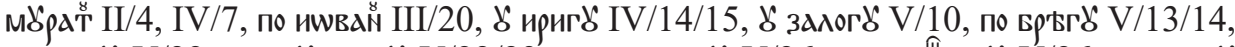

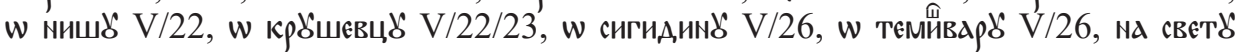

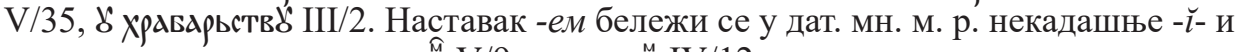
консонантске промене: хюд, -̌̆- промене долази старији облик люди V/6, 11. Старији наставак -jу у инстр. јд. именица ж. р. некадашње -ц- промене потврђен је у примерима мокью V/13

17 Потврде наставка - $а$ у ген. мн. именица бележимо у признаници деспота Стефана Бранковића о пријему дела очеве оставе (12. август 1457. године) (уп. Поломац 2016: 229).

${ }_{18}$ Мешање ова два падежа у једнини забележено је у једном примеру и у повељи деспота Ђурђа Бранковића Дубровнику (17. септембар 1445): при стопочившаго кмєзд лдздра, и при

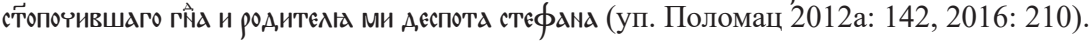

${ }^{19}$ Неразликовање ова два падежа бележимо и у признаници деспота Лазара Бранковића

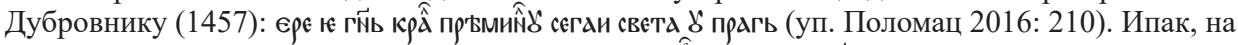

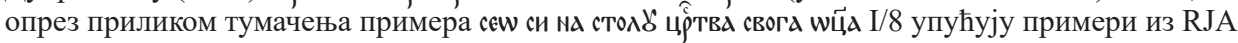
$\mathrm{XV}: 169$, у којима се види да се ради о устаљеном изразу. 
и светлостью V/18. Један српскословенски облик ген. јд. ж. р. долази у уводној формули адресације: и всакє потене чेти и слдви III/1 (уП. у истом Писму и српске облике странє III/15, 18 и ва̊ке III/16).

У категорији заменица и придева - поред горенаведених примера са -ем у инстр. и лок. јд. и дат. мн. и -ех у ген. мн. - потребно је указати још и: а) на примере личне заменице 1. лица јд. у духу народног језика: ґа III/14, V/2, 18, rad I/24, II $/ 5, \mathrm{~V} / 25,34,6)$ на множинске падеже личне заменице 1. и 2. лица: мд II/4, м๙ III/13, 16, ва̊ III/18 (ген.), ма̃ I/4, 5, 10, 13, III/5, 23, IV/5, 6, намь I/7, 9, IV/4 (дат.), ми IV/9 (дат.), в $\mathrm{d} I / 23$ (акуз.), вдми I/18, 19, 22, 27, III/22 (инстр.), в) на акуз. мн. ж. p. заменице 3. лица: дл мб ㅌ вєрठ̆ю цртво ти IV/8/9, г) на употребу општих заме-

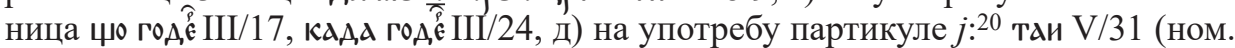
јд. м. р.), шваи V/32 (акуз. јд. м. р.), таи V/16, 37 (акуз. јд. м. р.), тогаи V/15, 36, 37 (ген. јд.), шнога⿱ V/33 (акуз. јд.), тои I/26 (ном. јд.), тои I/26, II/4, III/8, 12, 13, IV/6, V/5, 16, 28, 34, т̊n III/23, V/4 (акуз. јд.), швон V/11 (акуз. јд.), ђ) на примере употребе придева неодређеног вида: Ґै А, живд Арьжи V/35.

5. У категорији глаголских облика најпре је потребно указати на фреквентне облике презента који ускључиво долазе у духу српског народног језика: а)

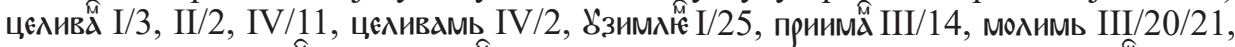
Адавамь V/11, Һеставй V/25, примай V/34 (1. л. јд.), б) хокюєшь $\mathrm{I} / 21, \mathrm{~V} / 17$, хокй III/24,

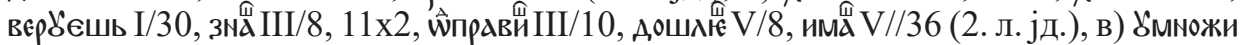
I/9, 30, II/5, IV/13, пишє I/6, 7, 10, поручل〕є I/6, 10, зна I/13, III/19, IV/3, V/1, 17 ,

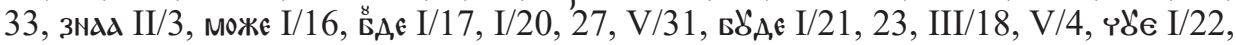
III/22, има III/1, 26, поге III/7, искажє III/13, кажє III/13, А.Гює III/26, Һૅзговори IV/8,

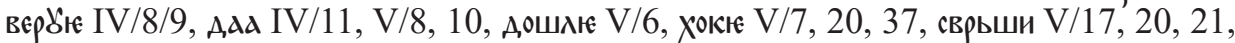
32, Һстави V/25, некю V/31, Арьжи V/35 (3. Л. јд.), г) покламнамо I/7, молимо I/20, 29, справимо I/26/27, III/17, пошлюе III/6, по̆тавимо III/27, сл丈'жимо IV/11 (1. Л. мн.), д)

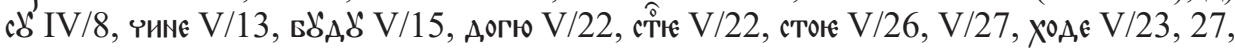
ил, б V/24, 26 (3. л. мн.). Међу наведеним примерима презента посебно истицање

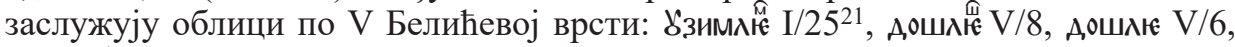
пошАюм III/6.

Поред облика 3. л. јд. и мн. аориста: А,гю I/4, догошє IV/4, кАзАшє IV/5, посебно истицање заслужују облици 1. л. мн. доследно са наставком -смо: ${ }^{22}$ примисм

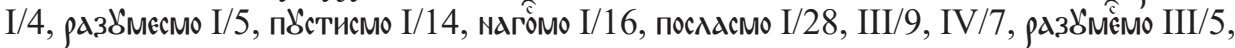
ठписасмо IV/7, порбчисмо IV/7/8. Великим бројем примера потврђени су облици

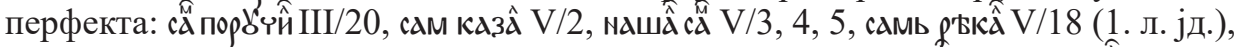

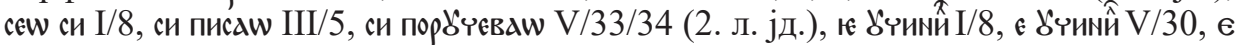

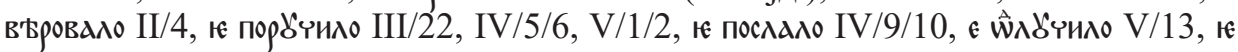

${ }^{20}$ Партикула је потврђена и у прилозима: дотлди I/17, V/23, такои III/18, т४и V/27.

${ }^{21}$ Облици овога глагола по V Белићевој врсти забележени су и у повељама деспота Ђурђа Бранковића (Поломац 2012a: 144), у једном писму султана Бајазита II Дубровнику из 1485. године (Лутовац Казновац 2019: 244), као и у савременим косовско-ресавским говорима (в. Ивић 2002: 9).

22 У писмима султана Мехмеда II Дубровнику срећу се у овом облику и -смо и -хмо, док се у писмима султана Бајазита II налази само -смо (уп. Лутовац Казновац 2019: 249). 


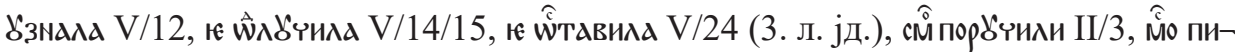

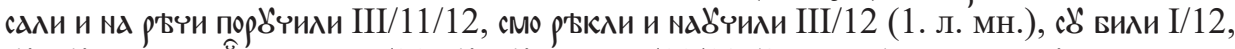

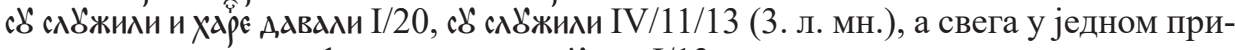
меру и плусквамперфекта: си виш порठъчиш I/13.

Поред очекиваних облика футура I: мєкщ чинити V/19 (2. л. јд.), кюе вити I/25/26, мєкю Бй III/16, мєкюе послати V/29 (3. Л. јД.), кюмо справити III/18 (1. Л. мн.), бележе се у 3. л. јд. и примери са енклитиком те (тє доки V/9, тє Ходити V/11), забележеном и у једном примеру у признаници деспота Лазара Бранковића Дубровнику из 1457. године (уп. Поломац 2016: 300-301), ${ }^{23}$ а карактеристичном и за савремене косовско-ресавске и источне призренско-тимочке говоре (уп. Ивић 2009: 170).

Забележени облици футура II и потенцијала не дају повода за шире

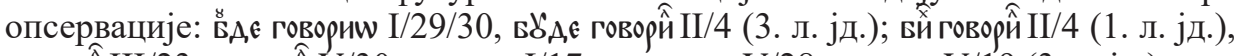

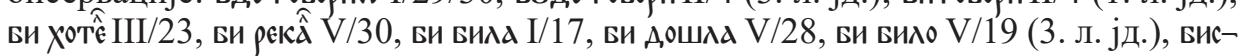
мо вили I/10, висмо слбжили I/19 (1. л. мн.). Поред очекиваних облика императива: вербй III/14, дли V/38, прими III/21, пошхи III/24, ЈстАви V/22 (2. л. јд.), посебно истицање заслужује облик императива у примеру: зА тои вигь твок цртво єли врњмє сдА, та ти посАิ чимити V/16/17, настао аналогијом према атематским глаголима, а потврђен како у старим споменицима (уп. Даничић 1874: 336) тако и у савременим говорима косовско-ресавског и призренско-тимочког дијалекта (уп. Ивић 2009: 168).

О процесу губљења партиципа и настанку глаголских прилога у српском народном језику сведоче примери стоєки I/19 и ч४̋вши I/14.

6. С обзиром на садржај и намену писама очекивана је употреба лексике страног порекла. У категорији оријентализама, поред личних имена Бајазит, Mурат и Али-бег, долазе владарске титуле султан, амира/амире, ${ }^{24}$ бег и хан, ${ }^{25}$ затим термини војног и државног устројства: баша, ${ }^{26}$ улак ${ }^{27}$ и харач. Посебно истицање заслужује лексема армаган „дар, поклон” (в. Škaljić 1966: 98): и чю ни ю цеंтво ти Армага̊ комґ послдло IV/10, која у RJA I: 110 долази само са потврдама из народне поезије. Међу осталим речима страног порекла потребно је указати на романизме каштел и капетан (титула деспота Вука Гргуревића, „заповедник града”, в. RJA IV: 841), затим на грецизам склав „слуга, роб” (уп. Vasmer 1944: 134, RJA XV: 241; детаљније о установи склава у ЛССВ: 671-672) и хунгаризам орсаг (мађ). ország, према RJA IX: 175 „држава, земља”, в. и русаг у ЛССВ 634-635).

7. На основу најважнијих језичких одлика писама деспота Вука Гргуревића може се закључити како је српски језик употребљен у њима изграђен на основи

${ }^{23}$ Ови су облици забележени и у двама писмима султана Мехмеда II Дубровнику (уп. Лутовац Казновац 2019: 258-259).

24 У средњовековним споменицима бележи се амир, амира и амире (уп. RJA I: 81).

${ }^{25}$ Према RJA III: 565 најстарије потврде долазе од 16. века.

${ }^{26}$ У нашим писмима у значењу „војни заповедник” (уп. ЛССВ: 503). У једном примеру: А на верб̆ вєликога ГПิ

27 У значењу „гласник” (Škaljić 1966: 631), према RJA XX: 487 са најстаријим потврдама из 16 . века. 
косовско-ресавског дијалекта с краја 15. века, чије су најважније одлике екавизам у низу морфолошких категорија (дат. и лок. јд. именица ж. р. са наставком -е, наставак -ем у инстр. и лок. јд. и дат. мн. и -ех у ген. мн. заменица и придева), вокал /a/ пореклом од /ə/, вокал /y/ пореклом од вокалног /л/, вокал /о/ пореклом од/л/ на крају слога, облици презента типа узимљем, облици футура I са енклитиком те и облици императива типа виђ. На основу ових, али и других забележених језичких одлика, може се пратити континуитет употребе одлика косовско-ресавског дијалекта у повељама и писмима 14. и 15. века - од повеља и писама кнеза Лазара и господина Вука Бранковића преко повеља и писама Српске деспотовине до повеља и писама деспота Лазара и Стефана Бранковића, писама султаније Маре Бранковић и писама деспота Вука Гргуревића. Пад Српске деспотовине и померање политичких активности на територију јужне Угарске нису оставили трага у језику писама деспота Вука Гргуревића насталим на тлу данашњег Срема, будући да њихов језички тип - како смо показали - одражава традиције пословноправне писмености Српске деспотовине. Поређењем писама деспота Вука Гргуревића са сачуваним српским писмима из угарских канцеларија 15. и 16. века може се закључити како се највише језичких подударности налази са писмом дворског судије и ердељског војводе Стефана Баторија Али-бегу Михалоглуу (1482-1489), ${ }^{28}$ нешто мање и са писмима краља Јована Запоље смедеревском санџак-бегу Мехмеду Јахијапашићу и његовом заменику Ферхату из 1537. године ${ }^{29}$ док се у основи српског језика писама угарског краља Матије Корвина из 15. века налази други дијалекатски тип. ${ }^{30} \mathrm{Ca}$ друге стране, графијско-правописне и језичке подударности које се уочавају између писама деспота Вука Гргуревића и писама турских султана Мехмеда II и Бајазита II Дубровнику, ${ }^{31}$ упућују нас на путеве могућих узајамних утицаја писмености из времена Српске деспотовине (и времена након њеног пада) и писмености Портине српске канцеларије.

\section{Цитирана литература}

Гошевъ, Иван. „Две новооткрити писма на „деспот Вукъ” до султанъ Баязитъ ханъ

${ }^{28}$ Детаљна филолошка анализа овога писма биће предмет посебног рада. За сада можемо указати само на екавизам у дат. јд. именица ж. р. и инстр. јд. заменица и придева (наставак -ем), као и на -смо и -хмо у 1. л. јд. аориста.

${ }^{29}$ У овим писмима бележи се вокал /a/ пореклом од /ə/, екавизам у дат. јд. именица ж. p. и лок. јд. придевских заменица, као и наставак -хмо у 1. л. мн. аориста (уп. Поломац 2020).

${ }^{30}$ На основу икавско-јекавске замене $ј а т а$, као и на основу места настанка писма, претпоставили смо да се у основи језика писма краља Матије Корвина фра Александру Дубровчанину (2. новембар 1465) могао налазити дијалекат из кога су се касније развили посавски, славонски и икавски и јекавски говори слива реке Босне (уп. Поломац 2018: 44). Детаљна филолошка анализа писма краља Матије Корвина султану Бајазиту II о прекршајима примирја на граници (25. јун 1487) биће предмет посебног рада. За сада можемо указати само на екавску и икавску замену јата у овоме писму.

31 У основи језика писама Портине српске канцеларије налази се народни говор близак данашњем косовско-ресавском дијалекту (уп. Лутовац Казновац 2019: 360). 
бегъ”. Известия на историческото дружство въ София XI-XII, 1932: 265-269.

[Gosheva, Ivan. „Dve novootkriti pisma na „despot Vuka” do sultana Bayazita hana bega". Izvestiya na istoricheskoto druzhstvo va Sofiya XI-XII, 1932: 265-269]

Грицкат-Радуловић, Ирена. „Језик Струшког преписа”. [У:] Мехмед Беговић (ур.). Законик цара Стефана Душана, књ. 1: Струшки и Атонски рукопис. Београд: САНУ, 1975, 125-157.

[Grickat-Radulović, Irena. „Jezik Struškog prepisa”. [U:] Mehmed Begović (ur.). Zakonik cara Stefana Dušana, knj. 1: Struški i Atonski prepis. Beograd: SANU, 1975, 125-157]

Даничић, Ђура. Историја облика српскога или хрватскога језика до свршетка XVII вијека. У Биограду: Издање и штампа државне штампарије, 1874.

[Daničić, Đura. Istorija oblika srpskoga ili hrvatskoga jezika do svršetka XVII vijeka. U Biograd: Izdanje i štampa državne štamparije]

Ђорђић, Петар. Историја српске ћирилице. Београд: Завод за уџбенике и наставна средства, 1991 (треће издање).

[Đorđić, Petar. Istorija srpske ćirilice. Beograd: Zavod za udžbenike i nastavna sredstva, 1991]

Ивић, Павле. „О језику писама султаније Маре”. Јужнословенски филолог XXX/12, 1973: 337-345.

[Ivić, Pavle. „O jeziku pisama sultanije Mare”. Južnoslovenski filolog XXX/1-2, 1973: 337-345]

Ивић, Павле. Српскохрватски дијалекти. Њихова структура и развој. Нови Сад Сремски Карловци: Издавачка књижарница Зорана Стојановића, 1994.

[Ivić, Pavle. Srpskohrvatski dijalekti. Njihova struktura i razvoj. Novi Sad-Sremski Karlovci: Izdavačka knjižarnica Zorana Stojanovića]

Ивић, Павле. „Жупски говор као најтипичнији представник косовско-ресавског дијалекта". Зборник Матице српске за филологију и лингвистику XLVI/1, 2002: 7-13.

[Ivić, Pavle. „Župski govor kao najtipičniji predstavnik kosovsko-resavskog dijalekta”. Zbornik Matice srpske za filologiju i lingvistiku XLVI/1, 2002: 7-13]

Ивић, Павле. Српски дијалекти и њихова класификација. Нови Сад - Сремски Карловци: Издавачка књижарница Зорана Стојановића, 2009.

[Ivić, Pavle. Srpski dijalekti i njihova klasifikacija. Novi Sad-Sremski Karlovci: Izdavačka knjižarnica Zorana Stojanovića, 2009]

Јовић, Душан. „О језику Закона о рудницима деспота Стефана Лазаревића”. Јужнословенски филолог XXVII, 1968/1969: 365-455.

[Jović, Dušan. „O jeziku Zakona o rudnicima despota Stefana Lazarevića”. Južnoslovenski filolog XXVII, 1968/1969: 365-455]

ЛССВ: Лексикон српског средњег века (ур. С. Ћирковић и Р. Михаљчић). Београд: Knowledge, 1999.

[LSSV: Leksikon srpskog srednjeg veka (ur. S. Ćirković i R. Mihaljčić). Beograd: Knowledge, 1999]

Лутовац Казновац, Тамара. Језик писама турских султана Дубровнику. Докторска дисертација у рукопису. Крагујевац: ФИЛУМ, 2019.

[Lutovac Kaznovac, Tamara. Jezik pisama turskih sultana Dubrovniku. Doktorska disertacija u rukopisu. Kragujevac: FILUM, 2019]

Митровић, Катарина. „Пет писама деспота Вука Гргуревића”. Браничевски гласник 3-4, 2006: 63-83. 
[Mitrović, Katarina. „Pet pisama despota Vuka Grgurevića”. Braničevski glasnik 3-4, 2006: 63-83]

Поломац, Владимир. „О језику повеља и писама деспота Ђурђа Бранковића са аспекта историјске дијалектологије". Зборник Матице српске за филологију и лингвистику LV/1, 2012a: 121-147.

[Polomac, Vladimir. „O jeziku pisama povelja i pisama despota Đurđa Brankovića sa aspekta istorijske dijalektologije". Zbornik Matice srpske za filologiju i lingvistiku LV/1, 2012a: 121-147]

Поломац, Владимир. „Језик повеља и писама деспота Лазара и Стефана Бранковића са аспекта историјске дијалектологије”. Српски језик XVII, 2012б: 333-359.

[Polomac, Vladimir. „Jezik povelja i pisama despota Lazara i Stefana Brankovića sa aspekta istorijske dijalektologije". Srpski jezik XVII, 2012b: 339-359]

Поломац, Владимир. „Ресавски правопис у повељама и писмима деспота Лазара и Стефана Бранковића", Митолошки зборник 29, 2013: 105-134.

[Polomac, Vladimir. „Resavski pravopis u poveljama i pismima despota Lazara i Stefana Brankovića", Mitološki zbornik 29, 2013: 105-134]

Поломац, Владимир. Језик повеља и писама Српске деспотовине. Крагујевац: ФИЛУМ, 2016.

[Polomac, Vladimir. Jezik povelja i pisama Srpske despotovine. Kragujevac: FILUM, 2016]

Поломац, Владимир. „О правопису и језику повеља и писама Вука Бранковића”. Зборник Матице српске за филологију и лингвистику LX/2, 2017: 59-71.

[Polomac, Vladimir. „O pravopisu i jeziku povelja i pisama Vuka Brankovića”. Zbornik Matice srpske za filologiju i lingvistiku LX/2, 2017: 59-71]

Поломац, Владимир. „Писмо краља Матије Корвина фра Александру Дубровчанину: текст и филолошки коментар". Philologica LXXXVII, 2018: 37-47.

[Polomac, Vladimir. „Pismo kralja Matije Korvina fra Aleksandru: tekst i filološki komentar". Philologica LXXXVII, 2018: 37-47]

Поломац, Владимир. „Два српска писма угарског краља Јована Запоље из XVI века: текст и филолошки коментар”. Археографски прилози 42 (2020): 51-75.

[Polomac, Vladimir. „Dva srpska pisma ugarskog kralja Jovana Zapolje iz XVI veka: tekst i filološki komentar”. Arheografski prilozi 42 (2020): 51-75]

Радојчић, Никола. „Пет писама с краја XV века”. Јужнословенски филолог XX, 1953-1954: 343-367.

[Radojčić, Nikola. „Pet pisama s kraja XV veka”. Južnoslovenski filolog XX, 19531954: 343-367]

Стојановић, Љубомир. Старе српске повеље и писма. књ. 2. Београд: СКА, 1934.

[Stojanović, Ljubomir. Stare srpske povelje i pisma, knj. 2. Beograd: SKA, 1934.]

Стијовић, Рада. „Неке особине народног језика у повељама кнеза Лазара и деспота Стефана” Јужнословенски филолог XLIV, 2008: 457-472.

[Stijović, Rada. „Neke osobine narodnog jezika u poveljama kneza Lazara i despota Stefana” Južnoslovenski filolog XLIV, 2008: 457-472]

Харисијадес, Мара. „Словенски рукописи у Библиотеци Сараја у Истанбулу”. Старинар XV-XVI, 1964-1965: 145-161.

[Harisijades, Mara. „Slovenski rukopisi u Biblioteci Saraja u Istanbulu”. Starinar XVXVI, 1964-1965: 145-161]

Deissmann, Adolf. Forschungen und Funde im Serai. Mit einem Verzeichnis der 
nichtislamischen Handschriften im Topkapu Serai zu Istanbul. Berlin und Leipzig: Walter de Gruyter \& Co, 1933.

RJA: Rječnik hrvatskoga ili srpskoga jezika. I-XXIII. Zagreb: Jugoslavenska akademija znanosti i umjetnosti, 1886-1976.

Škaljić, Abdulah. Turcizmi u srpskohrvatskom jeziku. Sarajevo: Svjetlost, 1966.

Vasmer, Max. Die griechischen Lehnwörter im Serbo-Kroatischen. Berlin: Verlag der Akademie der Wissenschaften, 1944.

\title{
Vladimir R. Polomac
}

\section{ON THE ORTHOGRAPHY AND LANGUAGE IN LETTERS BY DESPOT VUK GRGUREVIĆ}

\begin{abstract}
Summary
The paper investigates the most important orthographic and linguistic features of four letters by Despot Vuk Grgurević (known in folk tradition as Zmaj-Ognjeni Vuk (engl. the Dragon-Fire Wolf) ) addressed to the Turkish Sultan Bayezid II during 1482 and 1483, as well as a letter sent in 1483 to Bayezid's military commander Ali Bey Mihalbegović. The aforementioned letters serve as a significant testimony to the use of the Serbian language in the diplomatic correspondence conducted from Hungary with the Turkish sultans and regional commanders in the late $15^{\text {th }}$ century. Due to the predominant absence of the features of Resavian orthography, the letters in question deviate from the majority of the charters and letters of Despot Đurađ Branković and his successors. On the other hand, by using the Serbian language based on the recognizable features of the KosovoResavian dialect of the $15^{\text {th }}$ century: 1) ekavism in a number of morphological categories: dat. and loc. sg. nouns f. with the suffix $-e$, the suffix $-e m$ in instr. and loc. sg. and dat. pl. and $-e h$ in gen. pl. of pronouns and adjectives, 2) vowel /a/ originating from $/ \mathrm{\partial} /, 3$ ) vowel /u/ originating from vocalic $/ 1 /, 4$ ) vowel /o/ originating from $/ 1 /$ at the end of a syllable, 5) forms of present in the form of uzimljem, 6) forms of future I with the enclitic te and 7) forms of the imperative of the type vid; letters by Despot Vuk Grgurević establish a continuity with charters and letters of the Serbian Despotate, along with the letters from the offices of the Turkish sultans Mehmed II and Bayezid II.

Keywords: Serbian, language of diplomacy, Despot Vuk Grgurević, historical dialectology, $15^{\text {th }}$ century.
\end{abstract}

